\author{
Andreja Žele \\ Filozofska fakulteta Univerze v Ljubljani
}

\title{
Vezljivost in družljivost kot dopolnjujoča se besedilna pojava v slovenščini
}

Prispevek predstavlja in komentira vezljivost in družljivost ter z njima povezane določene pomensko- in strukturnoskladenjske pojave kot kookurenca/sopojavljanje, koreferenca/soodnos in disjunkcija/ločevanje v slovenščini. Hkrati opozarja na njihove pomenske, skladenjske in izrazne lastnosti v slovenskih povedih.

The article presents and comments on valency and optionality in relation to certain semantic- and structural-syntactic phenomena, such as co-occurrence, co-reference, and disjunction in Slovene. It furthermore points out their semantic, syntactic, and expressive properties in Slovene sentences.

Vezljivost in družljivost se kot pomensko-slovnična pojava v povedih vzajemno dopolnjujeta. Vezljivost iz pomena $\mathrm{v}$ besedilo vnaša skladenjsko urejenost in organiziranost, družljivost pa skladenjske zmožnosti pomenov dodatno osmišlja in jih širi tudi mimo glagolske vezljivosti.

\section{Opredelitve}

Vezljivost v smislu pomenske usmerjenosti je pomenska in slovnična lastnost zlasti glagolov pa tudi izglagolskih pridevnikov in samostalnikov, da odpirajo napovedljivo število skladenjskih mest (obveznih in neobveznih) in da vežejo določeno število udeležencev z določenimi udeleženskimi vlogami; vsak udeleženec vsakič nastopa samo v eni udeleženski vlogi in je izražen z enim določilom. Razmerje glagol - povedek pa zahteva ločevanje med glagolsko vezljivostjo v okviru glagolskih leksemov (glagolskih iztočnic v slovarju) in povedkovo vezljivostjo v okviru stavka, slednje je raba konkretnega glagolskega pomena $\mathrm{v}$ stavku. ${ }^{1}$

Družljivost kot pomenska sopojavnost ali soobstoj temelji na pomensko-slovnični smiselnosti, ki z udeleženci na nenapovedljivih prostih skladenjskih mestih omogoča glagolom, pridevnikom idr. smiselne vzajemne pomenske povezave.

${ }^{1}$ Aktualna raba primerov $\mathrm{v}$ prispevku je potrjena $\mathrm{v}$ besedilnem korpusu Nova beseda: http://bos.zrc-sazu.si/s_beseda3.html. 
Stavčna poved, ki vključuje dve propoziciji, lahko vključuje tako vezljivost kot družljivost, je npr. Janez hodi bos v pomenu 'Ko Janez hodi, je navadno bos'; povedkovodoločilna vezljivost v Janez je bos je pretvorbno vključena v Janez hodi bos, in Hodi bos je obvezna družljivost - skratka, pogoj obvezne družljivosti znotraj stavčne povedi je pomenska družljivost glagolov ali povedkova sopojavnost oz. kookurenčnost glagolov biti in hoditi.

Potrditev besedilnosti ${ }^{2}$ tako vezljivosti kot družljivosti so izsamostalniška prislovna dopolnila, ki skladenjskopomensko navezavo $\mathrm{z}$ glagolom vzpostavijo $\mathrm{z}$ impliciranim udeležencem v prislovnem določilu, ki glagolu prisoja zlasti obveznodružljivo vrstnost, npr. Včasih je tekmovalno smučal, danes pa smuča le ljubiteljsko, kar lahko razvežemo v 'Včasih je smučal in bil je tekmovalec, danes smuča in le kot ljubitelj'; v tovrstnih primerih tekmovalca in ljubitelja češka slovnica poimenuje tudi »kopredikátový komplement«, ki uvaja povedkovodoločilno vezljivost. ${ }^{3}$ Vezljiva prislovnodoločilnost $\mathrm{v}$ isti propoziciji pa je $\mathrm{v}$ primerih kot To se upravlja daljinsko ali ročno 'upravljati na daljavo / z roko'.

Tako vezljivost kot družljivost sta izhodiščno skladenjskopomenska pojava, na formalni/izrazni ravnini pa je v slovenščini uveljavljena delitev na vezljiva določila in družljiva dopolnila.

Vezljivost $\mathbf{z}$ vidika medpropozicije ${ }^{4}$ je najenostavneje predstavljena $\mathrm{z}$ vezljivimi stavčnočlenskimi propozicijami, ki so vsebinski odvisniki eno-, dvo- ali večvezljivega povedka: enovezljivost: Je dobro, če si aktiven, Dovolj je, da se opozori, Je škoda, če se ostane kar doma; dvovezljivost: Kaj dela, mi je neznanka, Posrečilo se mu je, da se je uspešno vrnil in trovezljivost: Poslali so mu, kar si je zaželel.

Prav znotraj prostorskih določil, ki so v okviru prislovnih določil najobsežnejša skupina, pa lahko poudarimo razmerja med vezljivostno obveznimi prislovnimi določili in nevezljivimi oz. družljivimi prislovnimi dopolnili, npr. vezljivo Živi doma / Gre domov nasproti samo družljivo, npr. Kmetuje doma / Staršem so pripeljali otroke nazaj domov.

Družljivost z vidika medpropozicije je glagolska družljivost oz. povedkova sopojavnost/kookurenčnost znotraj večstavčne povedi. Skratka, ni ravno smiselno trditi *Janez se je odločil zboleti /, da bo zbolel/ ali *Janez je oprostil ženi, da je inteligentna, povsem navadno pa je Janez se je sprijaznil z boleznijo ali Janez je oprostil ženi, da je odšla od njega ali Janez se je sprijaznil, da je žena odšla od njega ipd.

Najširše možnosti uporabe tako vezljivih določil kot obveznodružljivih dopolnil imajo splošnopomensko in oslabljenopomensko rabljeni glagoli.

${ }^{2}$ Besedilnost je tu dosežena z razmerjem najmanj dveh propozicij v povedi. Propozicija je pomenska baza oz. podstava stavčne povedi in ta pomenska podstava je sestavljena iz besed, bistvenih za oblikovanje in razumevanje sporočila povedi.

${ }^{3}$ Več v razpravi Medpropozicijskost z vidika družljivosti glagolov oz. povedkov (Žele 2014).

${ }^{4}$ Medpropozicija kot razmerje med propozicijami in vsi jezikovni pojavi, povezani z njo, so podrobneje predstavljeni in razloženi v mojem priročniku Slovenska besedilna skladnja $z$ jezikovnosistemskega vidika - temeljni pojmi (Žele 2013). 


\subsection{Vezljivost glagolov, družljivost sopojavnih glagolov (kookurenčnost) in po- sledični soodnosi udeležencev glagolskega dejanja (koreferenčnost)}

Izhodiščni onomaziološki vidik (iz pomena v izraz) je hkrati tudi vezljivostni vidik. Vezljivost in z njo povezani skladenjski pojavi zahtevajo obravnavo na treh ravneh: 1) na logični (ustrezna izbira glede na vzajemno ustreznost povedja in udeležencev), sledita 2) pomensko- in strukturnoskladenjska predstavitev in 3) izrazna predstavitev (z možnostjo obvezne in neobvezne izrazitve oz. z nezmožnostjo izrazitve) - iz zgornjih obravnav izhajajo 1) logične formule, 2) pomenskopodstavni oz. propozicijski obrazci in 3) izrazni/eksplicitni obrazci; v slovenščini je na izrazni (formalni) ravnini uveljavljena delitev na vezljiva določila in družljiva dopolnila.

Pomensko zapletenejši glagoli oz. jedrni povedki višjega reda v glavnem stavku vzpostavljajo sopojavljalno ali sodogajalno razmerje $\mathrm{z}$ notranjim povedkom odvisnega stavka, tako da vključujejo razmerne seme, ki navadno omogočajo oz. odpirajo skladenjske vloge pomensko manj zapletenim glagolom oz. notranjim povedkom prvega reda. Kookurenčno/sopojavno razmerje med jedrnim in notranjim povedkom vzpostavlja koreferenčno/soodnosno razmerje med prvim udeležencem notranjega povedka in prvim udeležencem jedrnega povedka pri glagolih tipa odločiti se, priznati, odvaditi se, obljubiti, obvezati se ipd. v Peter se je odločil, da odpotuje, Peter je obljubil, da se bo poboljšal, Peter se je obvezal Ani, da bo varoval skrivnost, in med prvim udeležencem notranjega povedka ter drugim udeležencem jedrnega povedka pri glagolih tipa obvezati, opominjati, sumiti, preprič(ev)ati ipd. v Peter je obvezal Ano, naj varuje skrivnost, Ana je prepričevala Petra, naj se oženi z njo.

Pri vsem tem je pomembno tudi osnovno spoznanje, da število udeležencev ni odločilno za število udeleženskih vlog, zato t. i. sestavljeni udeleženci odpirajo glede na število relevantnih udeleženskih sestavin (semov) tudi določeno število udeleženskih vlog - t. i. pomensko- in strukturnoskladenjska razstavitev udeleženca na sestavine, ki prevzamejo določene udeleženske vloge. Tovrstna metonimična zapolnitev udeleženskih vlog s sestavinami istega udeleženca uvaja t. i. (označevalno) disjunkcijo sestavin istega udeleženca v primerih kot Poljubil jo je na lice, Frizer je obril Janezu brado, $\mathrm{Na}$ glavo mu je položil venec, Dekle se je s hrbtom obrnilo proti svetlobi.

Meja med disjunkcijo (ločevanjem) in koreferenco (soodnosom) je lahko zabrisana $\mathrm{v}$ primerih, ko se v poved vključena glagol in izglagolska tvorjenka povezujeta $\mathrm{z}$ istim udeležencem, npr. Julija draži Majo s pretirano zaskrbljenostjo (nasproti kondenzaciji, ki kljub zgoščanju mora razbiti dvoumnost v Julijina pretirana zaskrbljenost draži Majo ali v Julija draži Majo zaradi njene pretirane zaskrbljenosti).

\subsubsection{Vezljivostne pomenske skupine slovenskih glagolov}

Z vezljivostnega vidika je smiselno upoštevati delitev glagolov oz. povedkov na tiste 'prvega/nižjega razreda' s samo predmetnimi udeleženci v enostavčni povedi in na glagole oz. povedke 'drugega/višjega razreda', ki so t. i. razlagalni oz. razmerni glagoli oz. povedki s tudi nepredmetnimi (pomenskopodstavnimi) udeleženci in udeleženskimi odvisniki v večstavčni (zloženi) povedi; sem sodijo tudi polnopomenski naklonski in fazni glagoli. 
Zaradi lažje primerjalne obravnave slovanskih skladenj je nastala tudi poenotena in poenostavljena delitev glagolov na pomenskovezljivostne skupine: ${ }^{5} 1$ statični glagoli (biti, prebivati, ležati, stati, dotikati se ipd), 1.1 statičnorazmerni glagoli z nadpomenko imeti (vsebovati, obsegati, želeti, hoteti ipd.), 2 procesni glagoli (postajati, trajati, boleti, celiti se ipd.), 3 dogajalni glagoli (dogajati se, preživljati, rasti ipd.), 3.1 operativni glagoli (ravnati, upravljati, usmerjati, gojiti ipd.), 3.2 kreativni glagoli (ustvarjati, oblikovati ipd.), 3.3 destruktivni glagoli (razbijati, ruvati, trgati ipd.), 3.4 glagoli premikanja (premikati (se), gibati (se), hoditi, iti ipd.). ${ }^{6} \mathrm{~S}$ pomenskoskladenjskega vidika oz. glede na določen skladenjski pomen v povedi se našteti glagoli pojavljajo kot povedki prvega/nižjega razreda ali kot povedki drugega/višjega razreda. ${ }^{7}$

Zgornja posplošena delitev se prekriva z glavno splošno delitvijo glagolov na vezljivostne pomenske skupine v slovenščini (le da skupina t. i. operativnih glagolov zaobjema tudi glagole govorjenja/mišjenja/razumevanja, skupina t. i. destruktivnih glagolov pa glagole sprememb in splošnih sprememb s premikanjem).

\subsubsection{Družljivo sopojavljanje glagolov (kookurenca) in posledični udeleženski soodnosi (koreferenca)}

Poleg sopojavljanja med povedki višjega reda kot t. i. jedrnimi glagoli in notranjimi povedki oz. povedki v odvisnikih se z vzporedno soorganizacijo udeleženskih vlog z ustreznimi udeleženci vzpostavlja tudi soodnos med udeleženci, ki omogoča vezljivo ali družljivo vključevanje istega udeleženca $v$ njuni vezljivostni polji v različnih udeleženskih vlogah. Lahko rečemo, da kookurenčnost v prvi vrsti izraža pomenskosestavinsko združljivost določenih vrst glagolov, posledično pa se ji pridružuje še pogoj koreferenčnosti/nekoreferenčnosti udeležencev.

${ }^{5} \mathrm{Za}$ potrebe primerjalne in kontrastivne obravnave slovanskih skladenj jo je izdelal S. Karolak. Monografija, ki podrobneje predstavlja in razlaga teoretično-metodološki pristop Stanisława Karolaka, je Od semantyki do gramatyki. Wybór rozpraw, Warszawa: Instytucia Slawistyki PAN, 2001.

${ }^{6}$ S. Karolak (2001: 22-25) glede na vezljivostne zmožnosti glagole podrobneje deli na glagole 1) hotenja, prizadevanja, pričakovanja, 2) čutenja, 3) pohvale, nagrade, poplačila, povrnitve, 4) procesov - umiranja, rasti, usihanja/venenja, omedlevanja, 5) dejavnosti - hoje, sprehajanja, vožnje, branja, pisanja, govorjenja, igranja, 6) dogodka - rojevanja, izginjanja, pojavljanja, vstopanja, odkrivanja, stvarjenja, 7) stanjskosti (biti čist/zadolžen/zaljubljen/suh/suša), 8) vede, znanja, resnice, vere, zavesti, razumevanja, 9) nameščanja, posajanja, prenehanja, pričakovanja, upanja, 10) vzroka (povzročiti, sprožiti), 11) zanikanja, ugovarjanja, oporekanja.

${ }^{7}$ Pod vplivom pomenskih delitev A. Wierzbicke (1972) S. Karolak (2001: 24-25) ločuje 'proste pomene' (pojęcia proste) in 'sestavljene pomene' (pojęcia złożone); sama proste glagolske pomene opredeljujem kot temeljne pomene, sestavljene glagolske pomene pa kot specializirane pomene. S. Karolak še dodaja logično ugotovitev, da na splošno v jezikih prevladujejo sestavljeni pomeni. T. i. sestavljene glagolske pomene deli v pomenske skupine glagolov 1) predvidevanja, pričakovanja, slutnje, 2) upanja, želje, 3) strahu, slutnje, 4) nanašanja, 5) obljube, veljave, 6) govorjenja, 7) zmote, 8) pomoči, 9) laži, 10) namere, 11) zanimanja, 12) maščevanja, 13) oštevanja, zmerjanja, 14) raziskovanja, preiskovanja. 


\subsubsection{Družljivo sopojavljanje glagolov (kookurenca)}

Družljivost oz. sopojavnost glagolov je jasno razvidna pri sopostavitvi določenih vrst glagolov: 1) glagoli odločitve, privolitve in obljube (odločiti se za, dogovoriti se, sporazumeti se, obljubiti ...) niso kookurenčni z glagoli stanja, neodvisnega od volje vršilca/nosilca, npr. bolezni, pohabljenosti, sramu, zmedenosti, inteligentnosti, podobnosti, tudi ne z glagoli volje, npr. hotenja, želje, poželenja, tudi ne z glagoli občutenja, npr. milosti, ljubosumnosti, zavisti, sovraštva, npr. *Peter se je odločil zboleti, *Peter je obljubil Ani, da bo zbolel, *Peter se je dogovoril, da bo zasovražil Anino prijateljico, *Peter je obljubil Ani, da bo zasovražil njeno prijateljico; 2) glagoli resignacije in tolerance (sprijazniti se z/s ...) so kookurenčni z glagoli stanja, neodvisnega od volje vršilca/nosilca, npr. bolezni, pohabljenosti, sramu, zmedenosti, inteligentnosti, podobnosti, npr. Janez se je sprijaznil s pohabljenostjo, Ana se je sprijaznila s svojo plahostjo, niso pa kookurenčni z glagoli volje, tudi ne z glagoli odločitve, pobude in ne $\mathrm{z}$ drugimi operativnimi glagoli, pri katerih je relevantna tudi udeleženska koreferenčnost/nekoreferenčnost, npr. nesmiselni *Peter se je sprijaznil s tem, da sovraži Ano (nasproti smiselnemu Janez se je sprijaznil s tem, da ga Ana sovraži), nesmiselni *Janez se je sprijaznil s svojo odločitvijo stopiti v zakon (nasproti smiselnemu Janez se je sprijaznil z odločitvijo staršev, da mora stopiti $v$ zakon), koreferenčna dvoumnost udeležencev dopušča izbiro pravilnega ali nepravilnega razumevanja primerov kot Janez tolerira to, da gleda na televiziji vse serije (nasproti enoumnemu Janez tolerira Ani to, da gleda na televiziji vse serije) ipd.; 3) glagoli odpuščanja, oprostitve, dopustitve niso kookurenčni z glagoli stanja, neodvisnega od volje vršilca/nosilca, npr. bolezni, pohabljenosti, sramu, zmedenosti, inteligentnosti, podobnosti, npr. *Janez je oprostil Tončki, da je inteligentna, in so kookurenčni z glagoli odločitve, pobude in z drugimi operativnimi glagoli, npr. Janez ji je oprostil, da je odšla od njega, Janez jim je prizanesel, tako da ni dajal nepotrebnih naukov ipd.

\subsubsection{Udeleženski soodnosi (koreferenca)}

Udeleženske soodnose omogočajo glagoli oz. povedki ‘drugega/višjega razreda' ali t. i. razlagalni oz. razmerni jedrni povedki z navadno nepredmetnimi (pomenskoskladenjskimi/propozicijskimi) udeleženci in udeleženskimi odvisniki v večstavčni (zloženi) povedi. Sem sodijo tudi naklonski in fazni glagoli v primerih kot Marija je hotela izbrati sodelavko izmed svojih sošolk, Marija se je odločila izbrati sodelavko izmed svojih sošolk ipd.

Možnost koreference je odvisna od pomenskih zmožnosti jedrnega glagola. Ločujemo:

1) obvezno koreferenco 1.1) prvega notranjega udeleženca $v$ odvisniku s prvim udeležencem ( $\mathrm{z}$ vršilcem/nosilcem dejanja $\mathrm{V} / \mathrm{Nd}$ ) v glavnem stavku z jedrnim povedkom z glagoli samodelovanja, samousmerjanja oz. vzvratnega delovanja, tj. predvsem z glagoli samo(vz)podbude v povedku, ki zahtevajo stalno (tj. pri vseh 
povedkih večstavčne povedi) /ne/tvorno udeležbo izhodiščnega vršilca/povzročitelja/pobudnika, npr. odločiti se, priznati, izpovedati (se), izogniti/izogibati (se), izgovoriti (se), odvaditi se, obljubiti, obvezati se, obtoževati se, kriviti se, skleniti, rešiti se, prevarati se, obvarovati se, presenečati, razburjati ipd. v Peter se je odločil, da odpotuje: Peter se je odločil za potovanje, Peter je priznal sodniku, da je ukradel uro: Peter je priznal, da je ukradel uro: Peter je priznal krajo ure, Peter je obljubil stař̌em, da se bo poboljšal: Peter je obljubil, da se bo poboljšal : Peter je obljubil svoje poboljšanje in 1.2) prvega notranjega udeleženca v odvisniku $\mathrm{z}$ drugim udeležencem (s prizadetim ali prejemnikom dejanja $\operatorname{Pr} / \operatorname{Pre}_{\mathrm{d}}$ ) v glavnem stavku z jedrnim povedkom z vplivanjskimi/ciljnimi glagoli tipa obvezati, očitati, opominjati, oponašati, spodbujati, nagovarjati, nadlegovati, osramotiti, ponižati, sumiti, preprič(ev)ati, zahtevati, pritiskati na ipd. v Peter je obvezal Ano, naj varuje skrivnost, Ana je prepričevala Petra, naj se omoži z njo : Ana je prepričevala Petra na možitev z njo, Ana je prepričala Petra, da se je odpovedal karieri: Ana je prepričala Petra $k$ odpovedi politične kariere, Marija je opominjala Marka, naj je ne moti; 2) neobvezno koreferenco prvega notranjega udeleženca v odvisniku s prvim ali drugim udeležencem ( $\mathrm{z}$ vršilcem/nosilcem dejanja $\mathrm{V} / \mathrm{Nd}$ ali s prizadetim ali prejemnikom dejanja $\operatorname{Pr} / \operatorname{Pre}_{\mathrm{d}}$ ) jedrnega povedka v glavnem stavku, npr. /pre/ strašiti (se), /raz/veseliti (se), /raz/žalostiti (se), odkrivati, spominjati se, pomniti, spoznavati, povpraševati, poizvedovati, privaditi se, navaditi se ipd. v Peter se je prestrašil, da je izgubil denar (nasproti Peter se je prestrašil, da je Ana izgubila denar), Janez je prestrašil znanca, da umira: Janez se je prestrašil, da umira: Janez se je prestrašil smrti, Peter se je razveselil, ker je podedoval imetje po stricu: Peter je razveselil starše, ker je podedoval imetje po stricu, in 3) obvezno nekoreferenco prvega notranjega/pomenskopodstavnega udeleženca s prvim ali drugim udeležencem (z vršilcem/nosilcem dejanja V/Nd ali s prizadetim/prejemnikom dejanja $\mathrm{Pr} /$ Pre $_{\mathrm{d}}$ ) jedrnega povedka v glavnem stavku, npr. domnevati, upati, pričakovati, distancirati se, tolerirati, upoštevati, prizanašati v npr. Andrej je domneval, da Ivana pred njim nekaj skriva, Janez se distancira od govoric, da mu sodelavci poskušajo odvzeti delo, Prevelikodušno tolerira napake, ki jih sodelavci namerno delajo.

Posebnost so koreferenčna razmerja pri neosebni naklonski uporabi glagola kot npr. v Petru se je posrečilo odditi z doma, Ani je preostalo zateči se v najbližje zavetišče, Mojci se je posrečilo potovanje z avtom v Grčijo, Ani je preostal pobeg $v$ najbližje zavetišče, Juretu se je posrečil vzpon na vrh, kjer je koreferenčni udeleženec nosilec dejanja $\mathrm{v}$ dativu.

1.1.2.2.1 Nekaj primerov 1) obvezne koreference, 2) neobvezne koreference in 3) obvezne nekoreference za dvoudeleženske glagole z logično formulo, kjer udeležensko vlogo zapolnjuje pomenskopodstavni oz. stavčni udeleženec:

1) obvezna koreferenca z glagoli kot prepričevati se, opogumljati se, ponašati se, bahati se, obvezovati se, obljubljati (si), očitati (si), izgovarjati se, upirati se ipd. 
v Prepričuje se / Opogumlja se / Ponaša se / Baha se / Obvezuje se / Obljublja (si), da on sam to zmore, Očita si, da sam ni dovolj ukrepal;

2) neobvezna koreferenca $z$ glagoli kot vedeti, upirati se, zavedati se, izgovarjati se, spominjati se, tožiti se, obžalovati, potrditi ipd. v Avtorica je vedela, da sama/ naslovnik ne more preprečiti katastrofe, Oče se je upiral, da bi njegovi otroci bili v slabi šoli, Tone se je zavedal, da sam/drugi ne morejo preprečiti nesreč, Prebivalci bloka so potrdili, da so oni/sosedi prišli domov;

3) obvezna nekoreferenca z glagoli kot slišati, posumiti, zahvaliti se, opazovati, ogledati si, opazovati, spremljati, vedeti ipd. v Obiskovalci so slišali, da so se v mestu naselili begunci, Tone je posumil, da je prijatelj dobil podkupnino, Gostitelj se je zahvalil, da so pevci obiskali njegovo gostišče, Obiskovalci so si radi ogledali, kaj s tolikšnimi tacami se skriva v kraški jami, Eksperti so opazovali in spremljali, kako ljudje s posebnimi starimi orodji izdelujejo že pozabljene izdelke.

\subsection{Glagolsko sopojavljanje in udeleženski soodnosi glede na vid in čas v stavč- nih povedih}

Pri pomensko- in strukturnoskladenjski obravnavi v okviru posameznih glagolskih pomenskovezljivih skupin je upoštevan tudi vid - tako z vidika tvorjenosti glagolov (npr. predponske tvorjenke oz. sestavljenke) ${ }^{8}$ kot tudi v smislu t. i. vidskega pomena stavka, ${ }^{9}$ ki naj bi se ga dalo docela razbrati šele iz stavčnega položaja, ker upošteva tudi stavčno organizacijo glagola in njegovih udeležencev.

Vsekakor pa je vidskost že v pomenju glagolov in zato soodloča o vezljivostnih pomenskih sestavinah in tako vpliva tudi na oblikovanje različnih razmerij propozicij $\mathrm{v}$ povedi.

\footnotetext{
${ }^{8}$ Vpliv tvorjenosti besed na njihovo vezljivost obravnava A. Vidovič Muha v razpravi Glagolske sestavljenke - njihova skladenjska podstava in vezljivostne lastnosti (1993). S primerjanjem glagolskih sestavljenk z njihovimi skladenjskopodstavnimi glagoli in z ustreznimi nesestavnimi glagoli, npr. izpisati : pisati iz : pisati, z upoštevanjem celotnega gradiva SSKJ ugotavlja, da je predponsko obrazilo pretvorba (vsaj) enega skladenjskopodstavnega glagolskega razmerja, kar zoži vezljivostno polje tvorjenega glagola (izjema so sestavljenke s samo faznim predponskim obrazilom). V razmerju med sestavnim (tvorjenim) in nesestavnim glagolom pa so spremembe predvsem v okviru leva - desna vezljivost, npr. izbuljiti oči : buljiti ipd.

${ }^{9}$ Gl. J. Orešnik (1994: 19, 67-77, 79) govori o »vidskem pomenu stavka«, in poleg navadnega glagolskega vida posameznih glagolov po C. S. Smithovi opredeli tipe univerzalnih vzorčnih stavčnih položajev s časovnimi značilnostmi stanje+/-, telično+/-, trajno+/-: a) stanje, $\mathrm{b}_{1}$ ) netelično $/ \mathrm{b}_{2}$ ) telično dogajanje, $\mathrm{c}_{1}$ ) netelični/ $\mathrm{c}_{2}$ ) telični dogodek (a) Kmetija stoji na hribu, Zna grško, Je priden, $\mathrm{b}_{1}$ ) Sprehaja se po parku, Smeji se, $\mathrm{b}_{2}$ ) Zidal je most, $\mathrm{c}_{1}$ ) Potrkal/Zakašljal je, $\mathrm{c}_{2}$ ) Razbil se je, Zadel je tarčo. Našteti vzorčni položaji glagolov v stavkih poudarjajo vsakokratno možno specifičnost organiziranja določenih udeležencev $\mathrm{v}$ določenih udeleženskih vlogah, kar spreminja sporočilnost. Šele povezava lastne vidske vrednosti glagola in časovnega ustroja določenega stavčnega položaja dá vidski pomen stavka.
} 
$Z$ vidika vida kot stalne slovnično-pomenske lastnosti glagolov so izhodiščne predvsem vidskopomenske skupine glagolov (vrste glagolskih dejanj glede na časovnost): ${ }^{10}$ - glagoli trajanja (statični in dinamični: dvoudeleženski: bedeti, biti $i z$, bivati, čakati, dotikati se, dovoljevati, gnezditi, hoteti; troudeleženski: dopuščati, dovoljevati, iskati, krasiti, nagovarjati), - trenutni (momentalni) glagoli (dvoudeleženski: dotakniti se, dovoliti, nehati, objeti; troudeleženski: dobiti, izkoristiti, obdarovati, okoristiti se), - inhoativni glagoli (dvoudeleženski: dobiti, dojeti, izgubljati se, občutiti, sestati se z/s; troudeleženski: poočitati (si)), - rezultativni glagoli (dvoudeleženski: izprositi, odvreči, pobeliti, počakati; troudeleženski: nagibati, nagovoriti, nameniti, namočiti), - telični glagoli (dvoudeleženski: boriti se za, čakati, dražiti, hoteti; troudeleženski: izobraževati, nagibati, nameščati), - habitualni glagoli (dvoudeleženski: bahati se, bati se, bivati; troudeleženski: dajati, dati se, dopovedovati, iskati); z bistvenim razmerjem med inhoativnimi glagoli in rezultativnimi glagoli, s tem da se pri inhoativnih spreminja vršilec oz. nosilec dejanja/procesa, pri rezultativnih pa predmet dejanja/procesa oz. prizadeto z dejanjem/ procesom.

$Z$ vidika vida kot predvsem pomenskoskladenjske kategorije in po načelu, da se časovnost najeksplicitneje izraža $v$ stavčnih povedih, pa obravnavamo vidske pomene stavkov oz. povedi glede na časovno-pomensko sosledje uporabljenih povedkov. Časovna razmerja med dejanskimi stanji v dvo- ali večstavčnih povedih, ki so označena $\mathrm{s}$ t. i. jedrnimi povedki ( $\mathrm{v}$ jedrnem stavku) in t. i. notranjimi povedki (v odvisnih stavkih), zahtevajo smiselno časovnopomensko usklajenost ustreznih vključenih povedkov - tj. usklajenost vidskih vrednosti glagolov v povedkih $\mathrm{s}$ t. i. časovnim ustrojem stavčnih položajev, kar celotni obravnavani stavčni povedi da določen vidski pomen. Smiselna časovnopomenska razmerja je možno predvideti z določenimi kombinacijami glagolov iz določenih vidskopomenskih glagolskih skupin (nujna posledičnospremstvena pojava sta glagolska kookurenca in udeleženska koreferenca). Jedrni povedek ( $\mathrm{tj}$. povedek jedrnega stavka) glede na svojo vidskopomensko skupino določa možno vidskopomenskost notranjega povedka ( $\mathrm{tj}$. povedka v odvisniku oz. v pomenskopodstavnem udeležencu), npr.: 1) predhodnost vsebine/pomena notranjega povedka glede na jedrni povedek - tipični glagoli v jedrnem povedku so: $d o$ voliti, obdolžiti, obsojati, očitati, oponesti, potrditi, pozabiti, priznati, tožiti, zanikati, zatajiti ... v Pozabila je, da je včeraj govorila drugače, Potrdili so, da se je zgodila nesreča (nasproti nekaterim možnostim časovno neaktualne rabe, npr. Pozabila je, da ji zdravnik prepoveduje kajenje, Obdolžuje ga, da jo zanemarja ...) ipd., 2) naslednjost (navadno tudi posledičnost) vsebine/pomena notranjega povedka glede na jedrni povedek - tipični glagoli v jedrnem povedku so: čutiti, napovedati, obljubiti, odrediti, predlagati, predvideti, prerokovati, pričakovati, pripravljati se, slutiti ... v Oče je predvidel, da hčerko pošlje v tujino, Prerokuje/Sluti, da ga čakajo hujši časi

${ }^{10}$ Vid je tudi v slovenščini obravnavan kot stalna (inherentna) slovnična lastnost oz. kot slovarskokategorialna lastnost glagolskega besedja. 
ipd., 3) istočasnost vsebine/pomena notranjega povedka in jedrnega povedka - tipični glagoli v jedrnem povedku so: gledati, izkazovati, ogledovati, opazovati, pokazati, poslušati, videti ... v Opazoval je, kaj se dogaja, Poslušal je, kako pojejo ptice ipd., 4) istočasnost ali predhodnost vsebine/pomena notranjega povedka glede na jedrni povedek - tipični glagoli v jedrnem povedku so: kritizirati, lagati, odobravati, poizvedovati, posmehovati se, povpraševati, pretvarjati se, pritoževati se, spominjati se, zasmehovati ... v Kritizira, kaj delajo ali Kritizira, kaj so delali, Pretvarja se, da vse ve ali Pretvarja se, da je vse slišal ipd.

Posebnost so tipični glagoli rekanja, npr. reči, povedati, v jedrnem povedku, ki dopuščajo oz. omogočajo poljubno izbiro glagolov v notranjem povedku odvisnega stavka, npr. Pravi / Povedala je, da se uči slovensko / da se je učila slovensko / da se bo učila slovensko, Peter je prepričeval mater, naj imetje prepusti najmlajšemu, Peter je prepričeval Ano, da se je Ivan preselil v mesto ipd.

$\mathrm{Z}$ dvoudeleženskimi glagoli, ki zajemajo oz. so vključeni v vse glagolske pomenske skupine, se lahko še najbolj nazorno prikaže združevanje glagolske kookurence (tj. smiselna združljivost glagolskih pomenov v povedkih iste povedi), udeleženske / ne/koreference (tj. obveznost/neobveznost ali neobstoj skladenjskopomenskih odnosov med udeleženci) in udeležensko-glagolske disjunkcije ( $\mathrm{tj}$. skladenjskopomenska delitev oz. ločevanje glagolskih in udeleženskih pomenov v več povedkov ali več udeleženskih vlog).

Vsi trije skladenjskopomenski pojavi, tj. kookurenca, koreferenca in disjunkcija, so prikazani v večpropozicijskih povedih tipa: Tone se je zavedal nezmožnosti preprečitve nesreč, Prebivalci bloka so potrdili prihod (svoj/sosedov) domov, Obiskovalci so slišali za naselitev beguncev, Od njih se pričakuje samo zmago, V njej je videl samo povzpetništvo; Molčanje naroda je povzročilo zaskrbljenost družbenih analitikov, Pokvarjenost ljudi omogoča velike kraje družbenega premoženja do izčrpanja; pri slednjih povzročiti že vključuje tudi vzročno-posledični vidski pomen, medtem ko npr. omogočiti za natančnejšo vidskopomensko določitev potrebuje tudi časovno prislovno določilo.

Kot so prikazali in dokazali zgornji primeri, medsebojna povezovanja in soodvisnosti slovnično-pomenskih pojavov še dodatno odkrivajo posamezne lastnosti in posebnosti jezika.

\subsection{Vezljivost in družljivost glede na eno- ali večpropozicijskost in nepropozicijskost}

Prehodnost med vezljivostjo in družljivostjo je pretvorbno razložljiva s t. i. vrstnimi izsamostalniškimi prislovi. Novejše slovenske jezikoslovne študije (prim. Slovensko leksikalno pomenoslovje A. Vidovič Muha 2000: 76-77) v okviru tipologije vrstnih prislovov (s samostalnikom v podstavi) eksplicitno odpirajo vprašanje propozicije globinskega udeleženca. Vrstni prislovi namreč pretvorbno vključujejo tako delovalnike (npr. sredstvo: računalniško, radijsko, medijsko) kot okoliščine (npr. kraj: ambulantno, tovarniško, laboratorijsko) - to so izudeleženska obpovedkova prislovna 
določila kot a) vezljiva določila To obdeluje samo strojno 's strojem', b) vezljiva določila ali družljiva dopolnila, npr. Politično in kulturno deluje 'deluje v politiki in kulturi' ali 'deluje kot politik in kulturnik', in c) družljiva dopolnila Že večkrat so ga ambulantno zdravili 'zdraviti v ambulanti' ipd.

Prvotno in prvenstveno prislovi natančneje določajo glagol glede na prostor, čas (ki sta takorekoč bivanjsko samoumevna), sredstvo (snov), spremstvo, vzrok; ${ }^{11}$ te izrazljive/zunanje okoliščine so navadno vezljive in zato hkrati tudi istopropozicijske, tj. $\mathrm{v}$ isti propoziciji, npr. laboratorijsko pregledati 'pregledati $\mathrm{v}$ laboratoriju', metodološko dokazati 'dokazati z metodo', prijateljsko deliti 'deliti s prijateljem' nasproti nepropozicijskim izpridevniškim prislovom v vlogi samo družljivih lastnostnih modifikatorjev tipa temeljito/dobro pregledati, redno poročati ali tipa vojaško pozdraviti 'pozdraviti kot vojak', hekersko delovati 'delovati kot heker', ki kot sestavine upovedovanja lastnostno opredeljujejo (modificirajo) glagolsko dejanje/dogajanje/stanje. Prostor in sredstvo kot konkretni entiteti in zato tudi samostojni propozicijski sestavini se lahko ubesedujeta implicitno (kot morfemski del glagola, npr. stražiti 'biti na straži', ponočevati 'biti (nekje) ponoči', krampati 'delati s krampom', moževati 'gibati se med možmi') ali eksplicitno kot /predložna/ imenska zveza (v ambulanti, z injekcijo) ali kot prislov (ambulantno, injekcijsko). Pri družljivih neistopropozicijskih lastnostnih (izglagolskih) deležijskih prislovih pa je cela propozicija v drugi propoziciji, npr. sede kuhati, kleče prositi, molče spremljati, in ker so to očitne vzporedne propozicije, je med njimi možna samo družljivost.

Meja med istopropozicijskostjo in nepropozicijskostjo je hkrati tudi meja med vezljivostjo in družljivostjo, npr. vezljivo propozicijsko: politično/ kulturno se udejstvovati ('udejstvovati se v politiki/kulturi') nasproti družljivo nepropozicijsko: politično/kulturno se udejstvovati ('udejstvovati se kot politik/ kulturnik').

\section{Za sklep}

Upoštevanje vzajemnega delovanja vezljivosti in družljivosti omogoča vpogled v skladenjske oz. besedilne zmožnosti jezika. Ključna pri vezljivostnih in družljivostnih zmožnostih slovenščine sta propozicijski in pretvorbeni vidik. Vse to skupaj teži k čim bolj celovitemu opisu besedilne skladnje.

\footnotetext{
${ }^{11}$ Jezikovna vzročnost je odraz fizične/materialne vzročnosti v mišljenju oz. zavesti.
} 


\section{Bibliografija}

Karolak, Stanisław. 2001. Od semantyki do gramatyki. Wybór rozpraw. Warszawa: Instytucia Slawistyki PAN.

Korpus Nova beseda: http://bos.zrc-sazu.si/s beseda3.html.

Orešnik, Janez. 1994. Slovenski glagolski vid in univerzalna slovnica. Ljubljana: SAZU.

Vidovič Muha, Ada. 1993. Glagolske sestavljenke - njihova skladenjska podstava in vezljivostne lastnosti (Z normativnim slovensko-nemškim vidikom). Slavistična revija 41/1: 161-192.

Vidovič Muha, Ada. 2000. Slovensko leksikalno pomenoslovje. Govorica slovarja. Ljubljana: Znanstveni inštitut Filozofske fakultete.

Wierzbicka, Anna. 1972. Semantic Primitives. Frankfurt: Athäneum.

Žele, Andreja. 2013. Slovenska besedilna skladnja z jezikovnosistemskega vidika-temeljni poj$m i$. Visokošolski učbenik. 1. natis. Ljubljana: samozal. 129 str.

Žele, Andreja. 2014. Medpropozicijskost z vidika družljivosti glagolov oz. povedkov. Slavia Centralis 7/2. 5-17.

Prispelo junija 2014, sprejeto aprila 2015

Received June 2014, accepted April 2015

\section{Vezljivost in družljivost kot dopolnjujoča se besedilna pojava $\mathrm{v}$ slovenščini}

Upoštevanje vzajemnega delovanja vezljivosti in družljivosti omogoča vpogled v skladenjske oz. besedilne zmožnosti jezika. Ključna pri vezljivostnih in družljivostnih zmožnostih slovenščine sta medpropozicijski in pretvorbeni vidik in vse to skupaj teži k čimbolj celovitemu opisu besedilne skladnje. Vezljivost z medpropozicijskega vidika je najenostavneje prestavljena $z$ vezljivimi stavčnočlenskimi propozicijami, ki so vsebinski odvisniki eno-, dvo- ali večvezljivega povedka, družljivost z medpropozicijskega vidika pa je glagolska družljivost oz. povedkova sopojavnost/ kookurenčnost znotraj povedi. Kookurenčnost v prvi vrsti izraža pomenskosestavinsko združljivost določenih vrst glagolov, na drugi stopnji pa se pridružuje še pogoj koreferenčnosti/nekoreferenčnosti udeležencev.

Vezljivost in $\mathrm{z}$ njo povezani skladenjski pojavi zahtevajo obravnavo na treh ravneh: 1) na logični (ustrezna izbira glede na vzajemno ustreznost povedja in udeležencev), sledita 2) pomensko- in strukturnoskladenjska predstavitev in 3) izrazna predstavitev ( $\mathrm{z}$ različno stopnjo izrazljivosti oz. z možnostjo obvezne in neobvezne izrazitve oz. z nezmožnostjo izrazitve). Poudarek je na koreferenci, ki jo omogočajo glagoli oz. povedki 'drugega/višjega razreda' ali t. i. razlagalni oz. razmerni povedki 
oz. tudi povedki z abstraktnimi glagoli s tudi nepredmetnimi (pomenskoskladenjski$\mathrm{mi} /$ propozicijskimi) udeleženci; sem sodijo tudi naklonski in fazni glagoli. Podrobneje so obravnavane 1) obvezna koreferenca prvega notranjega/pomenskopodstavnega udeleženca $v$ odvisniku s prvim udeležencem ( $\mathrm{z}$ vršilcem/nosilcem dejanja) jedrnega povedka z glagoli samodelovanja, samousmerjanja oz. vzvratnega delovanja in obvezna koreferenca prvega notranjega/pomenskopodstavnega udeleženca $\mathrm{z}$ drugim udeležencem (s prizadetim ali prejemnikom dejanja) jedrnega povedka z vplivanjskimi/ ciljnimi glagoli, 2) neobvezna koreferenca prvega notranjega/pomenskopodstavnega udeleženca s prvim ali drugim udeležencem (z vršilcem/nosilcem dejanja ali s prizadetim ali prejemnikom dejanja) jedrnega povedka in 3) obvezna nekoreferenca prvega notranjega/pomenskopodstavnega udeleženca s prvim ali drugim udeležencem ( $\mathrm{z}$ vršilcem/nosilcem dejanja ali s prizadetim/prejemnikom dejanja) jedrnega povedka. Pri pomensko- in strukturnoskladenjski obravnavi v okviru posameznih glagolskih pomenskovezljivih skupin je upoštevan tudi vid - tako z vidika tvorjenosti glagolov (npr. predponske tvorjenke oz. sestavljenke) kot tudi v smislu t. i. vidskega pomena stavka. Z dvoudeleženskimi glagoli, ki zajemajo oz. so vključeni v vse glagolske pomenske skupine, je možen popoln prikaz združevanja glagolske kookurence (tj. smiselna združljivost glagolskih pomenov v povedku) in udeleženske /ne/koreference (tj. obveznost/neobveznost ali neobstoj skladenjskopomenskih odnosov med udeleženci).

\section{Valency and Optionality as Complementary Textual Phenomena}

Taking into account the interaction between valency and optionality allows further insight into the syntactic or, rather, textual capacities of language. When the valency and optionality capacities of Slovene are considered, the inter-propositional and transformative aspects are crucial, as they facilitate a complete description of textual syntax. From an inter-propositional view, valency is best introduced by valent sentence element propositions that function as content-based subordinate clauses of the uni-, bi-, or multi-valent predicate, whereas optionality occurs as verbal optionality or, rather, as co-occurence within a sentence. The latter primarily expresses the semantic optionality of certain types of verbs, and secondarily stresses the (non) co-reference of the participants

Valency and the syntactic phenomena related to it must be treated on three different levels: (1) the logical level (the appropriate selection in terms of mutual appropriateness of the predicate and the participants); (2) the level of the semanticand structural-syntactic presentation; (3) the expressive level or, rather, the level of expressibility presentation (with various levels of expressibility, i.e., with the possibility of obligatory or optional expression or with lack of that possibility). The emphasis is on co-reference enabled by verbs or, rather, predicates of 'the second/higher rank' and/or the so-called explanatory or relative predicates and/or 
predicates with abstract verbs that can have non-object (semantic-syntactic/propositional) participants (including modal and phrasal verbs). The following phenomena are treated in more detail: (1) the obligatory co-reference of the first internal/ semantic-base participant with the first participant (agent) of the central predicate with verbs of auto(matic)-action and self-direction and/or reverse action and the obligatory co-reference of the first internal/semantic-base participant with the second participant (patient) of the central predicate with verbs of influence/goal; (2) the optional co-reference of the first internal/semantic-base participant with the first or second participant (agent or patient) of the central predicate; (3) the obligatory absence of co-reference of the first internal/semantic-base participant with the first or second participant (agent or patient) of the central predicate. In semantic- and structural-syntactic treatment within individual verbal semantic-valency groups, the aspect is also considered, both in terms of verbal word formation (e.g., prefixed verbs) and the so-called aspectual meaning of the sentence. With verbs that have two participants, which are present in all verbal semantic groups, it is possible to accurately demonstrate the joining of verbal co-occurrence (i.e., semantic compatibility of verbal meanings in the predicate) and the participant co-reference or the lack of it (i.e., obligatoriness/non-obligatoriness or the non-existence of syntacticsemantic relations between the participants). 